\title{
Evaluation of Capital Cost: Long Run Evidence from Manufacturing Sector
}

\author{
Mantas Markauskas, Asta Saboniene
}

\author{
Kaunas University of Technology \\ K. Donelaicio st. 73, LT-44029, Kaunas, Lithuania \\ E-mail.mantas.markauskas@ktu.edu,asta.saboniene@ktu.lt \\ cross $^{\text {ref }}$ http://dx.doi.org/10.5755/j01.ee.31.2.21439
}

\begin{abstract}
The article is directed to determine the most appropriate method for evaluating cost of capital of a manufacturing sector and, using the methodology, to perform a case study of Lithuanian manufacturing sector. For the evaluation of capital cost, calculation of Weighted Average Capital Cost was chosen, as literature analysis distinguished this method as the most widely accepted and used. The most popular methods for cost of capital evaluation prevent investors from estimating capital cost in countries, which do not contain liquid, mature financial markets. This paper contributes to methodology of WACC assessment by adapting the method for less liquid markets with new techniques, like using country's credit ranking to measure risk premium and adding it to base premium of mature equity markets. The paper also evaluates, how much changes in WACC affect long-term investments into fixed assets in Lithuanian manufacturing sector. The case study of Lithuanian manufacturing sector was performed for the period of 2001-2016. Empirical study revealed that required rate of return on separate WACC components evolved differently between the years of 2001-2016. Average annual return on equity for the period 2001-2016 was $7.7 \%$, while average annual return on debt was only $4.4 \%$. In the year 2015, the weight of equity capital, exceeded $50 \%$ first time during the analysed period. In the same year, ratio of net profit before taxes to total assets of Lithuanian manufacturing sector also reached the highest value at the time, later surpassed in 2016. This fact demonstrates that increased free cash flows from the operations were reinvested into further development of the companies. To maximize value of the shareholders, it would be preferable to pay out a portion of earnings as dividends and finance growth with debt, as it is currently a cheaper alternative.
\end{abstract}

Keywords: Cost of Capital; Weighted Average Capital Cost; Lithuanian Manufacturing Sector, Return on Debt, Return on Equity.

For a company to become competitive and successful, it needs to create value for the shareholders by employing resources in an efficient manner. Process of value creation can be defined as the ability to consistently generate and reinvest cash flows in projects, whose returns exceed cost of capital (Subramanyam, 2014). Analysts assess company's economic value in terms of free cash flows, which are available to be paid out as dividends after the necessary payments are made to reinvest in operating assets and meet required debt payments (Wahlen et al. 2010). Therefore, ability of value creation is also reflected in company's stock price and is closely associated with the value (and wealth) of shareholders (Becerra, 2009).

In order to assess company's capacity of value creation, adequate measurement methods are required. Proper techniques help to evaluate competence of different tier managers by assessing their ability to generate divisional operating profits, which exceed the relevant cost of capital (Grant, 2003). After the global economic crisis, some of the praised indicators of economic value measurement (for example, Economic Value Added) in some of the large corporations are becoming obsolete (Perez, 2011). Because of that, suitable and timely methods for determination of value creation should be employed.

According to Aubert et al. (2017), weighted average cost of capital (from now on abbreviated as WACC) is one of the most important determinants for shareholder value creation. Business managers and regulators employ WACC for investment decisions, rate regulations, restructuring activities, bankruptcy valuations (Rao \& Stevens, 2007). Many theoretical and empirical studies were dedicated to examine aspects of WACC. Opinions concerning the analysed measure differ greatly between authors. Miller (2009) suggests that WACC calculation method should be adjusted, as its linear approach is inadequate to evaluate project's payback period. Pierru (2009) states that WACC fails to correctly remunerate shareholders and bondholders, as project's debt to equity ratio changes throughout the investment period, which is not assessed in the calculation of measurement method. Keef et al. (2012) add by stating that there is no need to calculate WACC in the world, where interest paid is not tax deductible and analysed method can be used to evaluate cost of capital in a static environment, where debt to equity leverage is constant. According to Graham \& Harvey (2001), economic value measurement methods, which include valuation of WACC, are dramatically more important than in the past, although in practice they might not be applied correctly. Miles \& Ezzell (1980) argue that WACC can be used as discount rate if a company is willing and capable of maintaining steady equity to debt leverage ratio (equity should be exogenous to market values). Arango et al. (2013) created methodology to calculate deflationary WACC rate for Brazilian electricity markets. WACC components (debt and equity) were evaluated individually in the research, later combined into a consolidated ratio. It was concluded that this approach was 
the correct one, as it was found that regularly calculated WACC did not have any connection with effective practices in the sector. Another drawback, which was pointed out in using WACC, is the assumed risklessness of employed debt capital (Rao \& Stevens, 2007).

There were various research papers published aiming to assess importance of capital cost for operation processes in separate countries and sectors. Dempsey (1998) evaluated the impact of personal taxes on the firm's WACC and investment behavior in the United Kingdom. It was concluded that dividend taxation had an impact on company's valuation and reallocation of funds from mature firms to younger, growing ones. Fatica (2018) stated that tax-adjusted user costs significantly influence capital accumulation. Albanez (2015) analysed behavior of listed Brazilian companies and concluded that in periods of more expensive equity capital, companies restructured their capital with larger share of debt. Case study by Britzelmaier et al. (2013) indicated that value-based management has become a key management approach for small and medium size companies, where WACC is used to determine cost of invested capital. Gupta et al. (2018) stated that firm level governance affects cost of equity in common law countries with high levels of financial development. Scholars consider a lot of other factors affecting the cost of capital, which are related to political risk (Belkhir et al., 2017), liquidity risk (Saad \& Samet, 2017), information disclosure (GarciaSanchez \& Noguera-Gamez, 2017; Dutta \& Nezlobin, 2017; Nahar et al., 2016) and corporate social responsibility (Suto \& Takehara, 2017; Cajias, 2014).

The aim of the article is to determine the most appropriate methodology for the evaluation of capital cost, which can be applied to manufacturing sectors, and perform a case study for Lithuanian manufacturing sector in order to assess, whether chosen proportions between equity and debt capital in companies of the sector maximize shareholder value.

Analysis of the literature showed that Weighted Average Capital Cost is the most widely used and accepted method of capital cost evaluation. Standard methodology of WACC calculation is adequate to evaluate capital cost of participants that operate in environments with mature financial markets, when for each time period WACC is recalculated using updated equity and debt capital ratios. In case of Lithuania and other countries with illiquid, developing financial markets, methodology of WACC calculation should be adjusted. Market returns for these countries or sectors should be evaluated by adding country's risk premium to base premium of already developed financial market, while risk premiums should be evaluated using default spreads of risk-free treasury bonds, taken from countries credit ratings.

The empirical analysis of Lithuanian manufacturing sector reveals that return on equity during 2001-2016 increased, although not linearly, while return on debt steadily contracted during the whole period due to decreasing risk premium, influenced by Lithuania joining the European Union in 2004. In 2016, weight of debt in the capital structure of Lithuanian manufacturing sector was at its lowest point, while cost of debt was close to being cheapest during the analysed period. Average annual required return on equity for companies in Lithuanian manufacturing sector during 2000-2016 was $75 \%$ larger, compared to average annual required return on debt. Book value of assets in Lithuanian manufacturing sector in 2016 was the largest out of all evaluated periods. Growing assets, in accordance with increasing equity share in total capital, demonstrate that increased free cash flows in manufacturing companies were reinvested into further development. Performed regression analysis indicated that estimated values of WACC in Lithuanian manufacturing sector have significant effect on investment decisions in tangible and intangible assets.

The contribution of the performed empirical research was the composed methodology, designed to evaluate capital cost in countries/sectors with less liquid financial markets where, for the most part, companies are not listed in stock exchanges. Also the originality of this article should be noted, as most of the research papers focusing on capital cost evaluation analyse countries with large financial markets.

The paper is organized as follows: the first section of the paper covers the review of the scientific literature, the second section introduces the methodology and data of the empirical study. The third section of the paper covers the results and findings of the conducted analysis. The paper ends with the implications of the research.

Table 1

Correlation between Market Interest Rates and Manufacturing Sector's Interest Rates

\begin{tabular}{|llc|cl|}
\hline Code & Name & $\begin{array}{c}\text { Correlation } \\
\text { coefficient }\end{array}$ & Code & Name \\
\hline C17 & Paper and paper products & $89 \%$ & $\mathrm{C} 20$ & Chemical products \\
\hline C16 & Timber products, excluding furniture & $89 \%$ & $\mathrm{C} 24$ & Metal processing \\
\hline C14 & Apparel & $88 \%$ & $\mathrm{C} 29$ & Motor vehicles \\
\hline C10 & Food products & $87 \%$ & $\mathrm{C} 18$ & Printing and reproduction \\
\hline C22 & Rubber and plastic products & $84 \%$ & $\mathrm{C} 25$ & Metal products, excluding machinery \\
\hline C31 & Furniture & $84 \%$ & $\mathrm{C} 27$ & Electricity equipment \\
\hline C28 & Other machines and equipment & $79 \%$ & $\mathrm{C} 13$ & Textile \\
\hline C26 & Computers and electronics & $77 \%$ & $\mathrm{C} 11$ & Beverages \\
\hline C15 & Leather and leather products & $72 \%$ & $\mathrm{C} 32$ & Other manufacturing products \\
\hline C33 & Machinery repairs and equipment & $66 \%$ & $\mathrm{C} 23$ & Other non-metal mineral products \\
\hline C30 & Other transportation equipment & $59 \%$ & $\mathrm{C} 21$ & Drugs and medical products \\
\hline
\end{tabular}




\section{Literature Review}

Indicator, which is very popular and vastly used in assessment of cost of the capital, is called Weighted Average Capital Cost (WACC) (Rao \& Stevens, 2007). There are many research papers, which analyze methods used for cost of equity capital evaluation. According to survey, carried out in 2011,87\% of all firms and $91 \%$ of publicly traded firms for cost of equity capital evaluation use capital asset pricing model (CAPM) (Michelfelder, 2015). Ward (1999) agrees that this method is widely used to calculate cost of capital. In Britzelmaier et al. (2013) paper it is written that $75 \%$ of financial professors suggest using CAPM to estimate cost of equity capital with regard to capital budgeting. Despite it's popularity, researchers express concern towards eligibility of CAPM. Michelfelder (2015) perceives weakness in either model's theory or it's empirical implementation, although he does not indicate that CAPM should be completely discarded.

There exists different reasons, presented in academic literature, which validate the use of WACC as a primary value evaluation measurement. Fernandez (2002) used WACC as an accurate benchmark determining whether performance of the companies is creating or destroying value. According to Pratt \& Grabowski (2010) WACC is the essential link, which enables investor to convert expected future income into an estimate of present value and allows to make informed pricing decisions, compare one investment opportunity against another, while Barth (2009) defines cost of capital as rate of return needed to make capital investment worthwhile, taking into account opportunity costs. WACC is also a great method to evaluate available tax shields for companies (Farber et al. 2006). Bade (2009) states that standardly used WACC formula is always valid if the measurement is calculated using correct debt to equity ratios (unless a time constant ratio is assumed). Frank \& Shen (2016) concluded that WACC is an important measure for corporate investment decisions. Brotherson et al. (2013) affirm that discounted cash flow is the main investment valuation technique, used by companies, and WACC is the prevailing estimation method applied in discounted cash flow analysis.

Cost of capital can be described in financial and economic terms (Pratt \& Grabowski, 2010). In financial terms it is the expected rate of return, which is required by market participants in order to attract funds to a particular investment. This expected rate of return depends on different conditions: contemporary risk-free rate, inflation, maturity risk, income uncertainty risk.

Cost of capital is a price which should be offered on the market in exchange for the received capital (either equity or debt). In economic terms, it is the rate of return needed to make capital investment worthwhile, taking into account cost of alternative investment methods (Barth, 2009). Although large enterprises for managerial practices use WACC less frequently after the financial crisis, which began in 2008, capital cost measurement and use as a motivational device is still widely employed in small and medium size companies (Britzelmaier et. al., 2013).

\section{Methods}

Formula for calculation of WACC is presented in the first equation (Schlegel, 2015):

$$
W A C C=w_{\text {equity }} * r_{\text {equity }}+(1-T) * w_{\text {debt }} * r_{\text {debt }}
$$

In the first equation $w_{\text {equity }}$ and $w_{\text {debt }}$ respectively present weights of equity capital and debt capital; $r_{\text {equity }}$ and $r_{\text {debt }}$ denote required return on equity/debt, while $\mathrm{T}$ represents corporate tax rate. A choice between financing company's (sector's) growth using either debt or equity capital depends on comparative cost of both alternatives (Albanez, 2015).

Second equation presents the formula for calculating return on equity, using Capital Asset Pricing Model:

$$
r_{\text {equity }}=r_{r f}+\beta_{i}\left(r_{m}-r_{r f}\right)
$$

In the given equation $r_{r f}$ presents risk-free rate of return, $r_{m}$ is the market rate of return and $\beta_{i}$ shows the volatility of rate of return within the examined company/sector, compared to the market rate of return. Risk-free rate of return is usually represented by earnings of high-quality government bonds, which are the safest alternative for investment (Lim \& McNelis, 2008). Beta can be estimated using three different methods (Kumar, 2016). Historical beta estimation is performed by regressing stock returns on market returns. Fundamental beta estimation is made by analysing stock prices of companies, which are traded in a market.

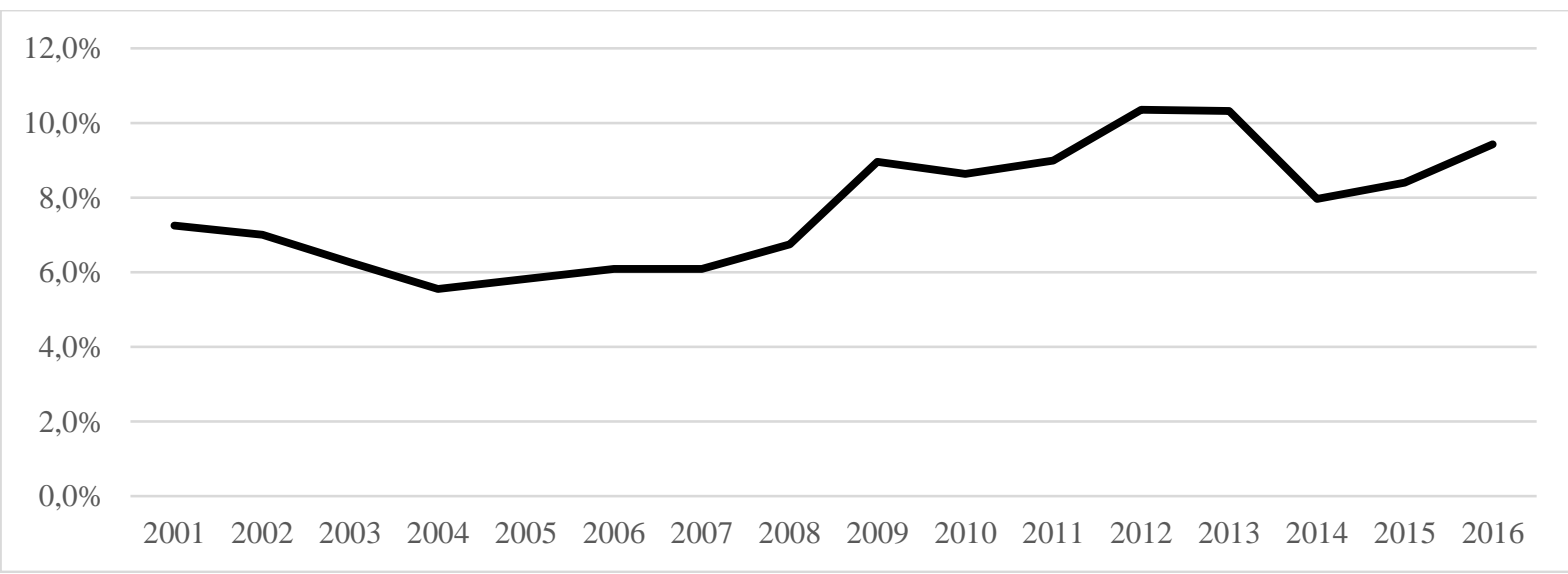

Figure 1. Required Rate of Return on Equity in Lithuanian Manufacturing Sector 
Accounting beta is calculated by regressing company's return on assets against the average return on assets for large sample of firms included in a market index. Risk premiums are calculated as difference between market rate of return and risk-free rate of return. Risk premiums in emerging markets with underdeveloped stock exchanges can be calculated by adding a country premium to a base premium of a developed market.

Estimation of beta value by the use of historical data is presented in third formula (Frank, Shen, 2016):

$$
\beta_{t+1}=\bar{\beta}+\rho_{\beta}\left(\beta_{t}-\bar{\beta}\right)+\sigma_{\beta} \varepsilon_{\beta, t+1}
$$

In the given formula first term represents the expected constant value of beta, second term represents the change of beta value, which is dependent upon current period beta value, and the third part represents standard deviation of the error term. $\rho_{\beta}$ and $\sigma_{\beta}$ are constants, which should be known to the market participants, while $\varepsilon_{\beta, t} \sim N(0,1)$.

For evaluation of financial leverage in cost of capital unleveraged beta is calculated. Method for evaluation of unleveraged beta is presented in fourth formula (Kumar, 2016):

$$
\beta_{L}=\beta_{U}\left(1+\left((1-T) \frac{D}{E}\right)\right)
$$

Leveraged beta is calculated by multiplying unleveraged beta by the ratio of debt to equity capital, adjusted for the tax shield effect.

Second part of the first formula represents debt capital. One of the ways to calculate cost of debt capital is to divide interest expense, obtained from the income statement by total long-term debt (Kumar, 2016). Corporate tax rate presents tax-saving or tax shield effect, as interest payments are tax deductible (Suto \& Takehara, 2017; Ward, 1999)

The analysed method of WACC evaluation with slight variations in the principles of variable calculation can be used not only to assess cost of capital for companies, but also for sectors (Grant, 2003).

Weighted Average Cost of Capital in Lithuanian manufacturing sectors for 2001-2016 period were calculated using the first formula. Weights for equity and debt capital were evaluated using data taken from
Lithuanian department of statistics. Return on equity capital was evaluated using the capital asset pricing model (second formula).

For the risk free rate annualized rates of return on 3 month United States treasury bills were used. As Lithuanian stock market is not as liquid and developed as in United States and some of the sectors do not have representative companies listed in NASDAQ OMX Vilnius stock exchange, market rate of return cannot be calculated as an annual market rate of return.

Market returns for countries with lesser developed financial systems can be evaluated by adding country risk premium to base premium for maturelly developed equity market (Kumar, 2016). Country's risk premium can be evaluated in accordance to its credit rating (Pratt \& Grabowski, 2010). Aswalt Damodaran, a professor in the field of finance, has created a database where already calculated country risk premiums and total risk premiums for different countries, starting from 2001, are presented. He used Moody's country credit ratings and estimated default spreads for different countries over the risk-free treasury bond rates. Damodaran has also observed beta values for different United States sectors on a yearly basis. In this research beta ratios for Lithuanian manufacturing sectors were calculated as the values from corresponding United States sectors, with Lithuania's risk premium added to the United States market rate of return. In the short term, according to Damodaran, country's equity risk premium is likely to be slightly higher, but as Lithuanian stock exchange is still at the developing stage and, especially in the early years of the analysed period, highly volatile, there is no better approach for estimating required return on equity on a year-to-year basis.

To estimate sectors rate of return on debt data from Lithuanian department of statistics was used. Rate of return on debt was calculated as annual interest paid by companies in each of the manufacturing sectors, divided by total book value of debt. From the year of 2016 business accounting standards in Lithuania have changed and from this year companies started submitting information about their annual interest payments.

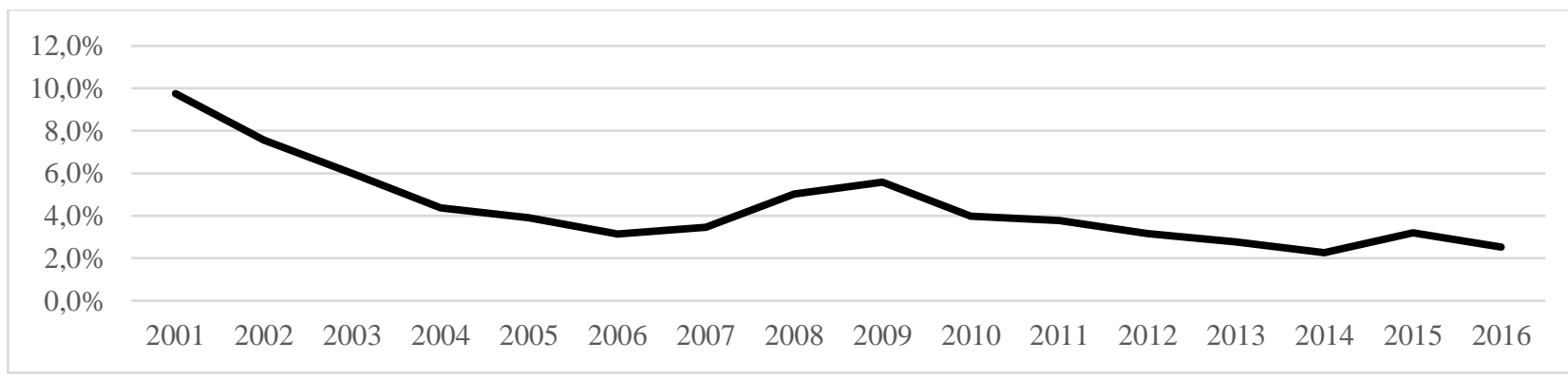

Figure 2. Required Rate of Return on Debt in Lithuanian Manufacturing Sector

Before that interest payments were presented in a consolidated form with other investment activity costs, although interest payments still made up the vast amount of these expenses. In order to evaluate whether other financial and investment expenses could be used as a proxy for interest expenses, Pearson correlation coefficient was estimated between Bank of Lithuania published loan interest rates provided to Lithuanian companies and interest rates calculated from the data given by Lithuanian department of statistics. The correlation coefficient was calculated for the period of 2005-2016. Results are presented in the Table 1. 
Information in the Table 1 shows that there is a strong linear correlation between interest rates, presented in Lithuanian bank's database, and interest rates of sectors calculated from data gathered from Lithuanian department of statistics database.

Out of 22 sectors presented 9 have a strong linear relationship between their paid interest rates and market interest rates, while for all but one sector coefficients are positively linear. The exceptional sector is drug and medical production sector, which interest rates during the last couple of years rose while on average return of debt in Lithuania decreased. All in all, interest rates calculated using data, gathered from Lithuanian department of statistics, can be used in the evaluation of WACC as the information presents a trend, which coincides with interest rate fluctuation of the whole Lithuanian lending market.

Last but not least, multiple linear regression was performed in order to assess how changes in WACC affect investment into fixed assets at sectoral level. There exist research papers with different variations of WACC impact on investment analysis. Frank and Shen (2016) use this equation as the basis of their analysis:

$$
\frac{I_{t}}{K_{t}}=\alpha_{0}+\alpha_{1} \frac{\text { CashFlow }_{t}}{K_{t}}+\alpha_{2} \text { WACC }_{t}
$$

In the 5 equation investment is depicted as a ratio of investment into fixes assets and value of capital stock. In the given formula cash flow to capital stock ratio is applied as a proxy for average profit.

Carluccio et al. (2019) used this equation to analyse WACC accounting for industry-specific values of the cost of equity:

$$
\begin{gathered}
\frac{I_{i, t}}{K_{i, t-1}}=\beta_{0}+\beta_{1} \frac{E B I T D A_{i, t-1}}{K_{i, t-2}}+\beta_{2} W A C C_{i, t-1}+ \\
\beta_{3} X_{i, t-1}+\beta_{4} Z_{s, t_{1}}
\end{gathered}
$$

Differently from the equation 5 , where proxy cash flows were used as a proxy for average profit, in equation 6 EBITDA is used as a measure of profitability. $X$ variable in equation 6 represents firm level controls while $\mathrm{Z}$ depicts sector specific controls which affect investment values of companies at macro level. The largest difference between the two given formulas is that equation 5 uses contemporary values of capital stock and WACC while equation 6 uses lagged values. To depict the effects of both contemporary and lagged values of variables on sectoral level investment decisions, two distinct regression equations were estimated and analysed:

$$
\begin{gathered}
\frac{I_{t}}{K_{t-1}}=\beta_{0}+\beta_{1} \frac{E B I T D A_{t-1}}{K_{t-2}}+\beta_{2} W A C C_{t-1}+ \\
\beta_{3} E X P_{t-1}+\beta_{4} C A P_{t-1}+\varepsilon_{t} \\
\frac{I_{t}}{K_{t}}=\alpha_{0}+\sum_{i=0}^{1} \beta_{i} \frac{E B I T D A_{t-i}}{K_{t-i}}+\sum_{i=0}^{1} \gamma_{i} W A C C_{t-i}+ \\
\sum_{i=0}^{1} \delta_{i} E X P_{t-i}+\sum_{i=0}^{1} \theta_{i} C A P_{t-i}+\varepsilon_{t}
\end{gathered}
$$

In the given equations 7 and $8 \mathrm{I}$ represents investment into tangible and intangible assets, $\mathrm{K}$ represents average annual capital value of companies in Lithuanian manufacturing sector. EXP represents export ratio (export turnover to total turnover) and CAP represents capital structure (equity capital to debt capital) of companies in Lithuanian manufacturing sector. Export ratio was included into regression equation to distinguish whether investment was made due to lower cost of capital and improving investment conditions or expansion into new markets. Emergence of investment opportunities in foreign markets can lead to increasing investment despite deteriorating price of borrowed funds. Capital structure was included into analysis as high debt-to-capital ratio can complicate borrowing funds for now investment projects even with favorable cost of capital values.

\section{Findings}

Figure 1 presents consolidated required rate of return on equity capital for all the Lithuanian manufacturing sectors. It was calculated as weighted average required rate of equity of each manufacturing sector. Weights were determined based on equity book values for each of the manufacturing sector at the end of the year.

It can be witnessed that required rate on equity steadily declined between 2001-2004 and reached its lowest value of $5.4 \%$ in 2004 . Lowest required rate of return coincided with Lithuania joining European Union, which decreased risk for the investors.

Capital Structure of Companies in Lithuanian Manufacturing Sector

\begin{tabular}{|c|c|c|c|c|c|c|c|c|}
\hline Year & $\mathbf{2 0 0 1}$ & $\mathbf{2 0 0 2}$ & $\mathbf{2 0 0 3}$ & $\mathbf{2 0 0 4}$ & $\mathbf{2 0 0 5}$ & $\mathbf{2 0 0 6}$ & $\mathbf{2 0 0 7}$ & $\mathbf{2 0 0 8}$ \\
\hline Equity share & $44 \%$ & $46 \%$ & $45 \%$ & $49 \%$ & $48 \%$ & $46 \%$ & $44 \%$ \\
\hline Debt share & $56 \%$ & $54 \%$ & $55 \%$ & $51 \%$ & $52 \%$ & $54 \%$ & $56 \%$ & $57 \%$ \\
\hline Year & $\mathbf{2 0 0 9}$ & $\mathbf{2 0 1 0}$ & $\mathbf{2 0 1 1}$ & $\mathbf{2 0 1 2}$ & $\mathbf{2 0 1 3}$ & $\mathbf{2 0 1 4}$ & $\mathbf{2 0 1 5}$ & $\mathbf{2 0 1 6}$ \\
\hline Equity share & $47 \%$ & $49 \%$ & $49 \%$ & $49 \%$ & $49 \%$ & $50 \%$ & $53 \%$ & $57 \%$ \\
\hline Debt share & $53 \%$ & $51 \%$ & $51 \%$ & $51 \%$ & $51 \%$ & $50 \%$ & $47 \%$ & $43 \%$ \\
\hline
\end{tabular}

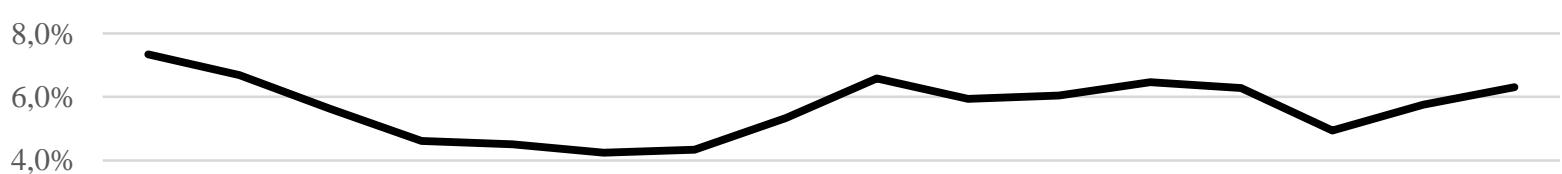

Figure 3. WACC of Lithuanian Manufacturing Industry 
Later rate of return increased up until 2009, the year when global financial crisis had the largest impact to the performance of companies in Lithuanian manufacturing sectors, reaching the value of $9.0 \%$. In 2016, the last year of the analysed period, required rate of return on equity slightly decreased down to $9.4 \%$, although the value is still a lot larger compared to the value observed in the period between 2004 2008. Compared to the pre-crisis period, rate of equity in Lithuanian manufacturing sectors is comparatively large as economic situation in all of the Europe has not fully recovered after economic slowdown. Figure 2 presents consolidated required rate of return for equity capital for all the Lithuanian manufacturing sectors. Highest cost of debt capital was observed during the first year of analysed period, $9.8 \%$.

After that cost of debt for Lithuanian manufacturing sector steadily declined up until the year of 2006 when it reached $3.1 \%$. The same factors apply to the diminishing cost of debt, as to cost of equity: Lithuania joined European Union, which decreased the adopted risk. Besides that, in 2002 local Lithuanian currency litas was pegged to euro in a fixed exchange rate which lowered the investors risk of capital losses due to fluctuation of exchange rates. Fixed exchange rate stimulated increasing loans, denominated in euros, which also put downwards pressure on cost of debt as euro was regarded as less risky currency and interest rates, paid on loans, taken out in euros, were lower.

From 2006 up until the financial crisis required rate of return on debt rose to $5.6 \%$ as economic activity during the period accelerated and return on investment for companies performing in Lithuanian manufacturing sector rose. Higher return on investment allowed companies to pay higher interest rates and still stay profitable, which had let to higher borrowing and more expensive debt. After the financial crisis required return on debt declined every year up until 2014, when the required rate of return on debt reached the lowest point during the whole analysed period, $2.3 \%$. In 2016 cost of debt was recorded as $2.5 \%$, second lowest value during all of the analysed period, and $55 \%$ lower, compared to the cost of debt in 2009.

Table 2 presents capital structure of companies in Lithuanian manufacturing sectors. During the first eight analysed years debt was larger then equity and made up between $51 \%-57 \%$ of total invested capital. After the global financial crisis, between 2010 and 2013, debt and equity capital almost equalized, total capital consisted of $51 \%$ debt and $49 \%$ equity for all of the period.

After 2013 share of debt started declining and in 2016 it made only $43 \%$ of total capital for companies performing in Lithuanian manufacturing sector. This happened because companies started earning larger profits and the decision was made not to pay out earned profits as dividends, but to reinvest part of the earning into further growth. Total equity for companies performing in Lithuanian manufacturing sector in the period of 2011-2016 increased by 2 billion euros while debt capital rose by almost 400 million euros, although cost of debt capital during this period was cheapest during the last 15 years, while cost of equity was the most expensive. During the later years of analysed period companies in Lithuanian manufacturing sector were operating in the most profitable fashion. In 2015 net profit before taxes to total assets ratio for these companies exceeded $10 \%$ mark for the first time in the evaluated period $(10.3 \%)$, while in 2016 ratio grew even more $(11.7 \%)$. This level of profitability was not reached even prior to the financial crisis, when in 2005 value of net profit before taxes to total assets ratio reached $9.8 \%$.

According to Stretcher and Johnson (2011) traditional capital structure theory states that although risk increases as the firm adds debt to capital structure, debt is very beneficial at lower levels since it is much cheaper and provides the tax shield. At first, increasing share of the debt lowers value of WACC. At some point, increasing debt creates additional risk, which rises WACC value. In the case of Lithuanian manufacturing industry, level of debt in total capital structure is not at the risky level as companies are using lowest share of debt during the last 16 years.

WACC of companies in Lithuanian manufacturing sector, presented in Figure 3, during the period between 2001 and 2006 declined from $7.3 \%$ to $4.2 \%$. The principal cause of decline was the diminishing rate of return of debt. After that WACC started growing and reached the peak of $6.6 \%$ right during the global financial crisis. This time growth was influenced by combined result of growing cost for both equity and debt. Until 2013 rate of capital cost stayed at the same level, while in 2014 it dropped to $4,9 \%$, while in 2016 it jumped back to $6.3 \%$. Between 2014 and 2016 cost of debt was decreasing, while cost of equity rose, but, because equity's share in total capital increased, it led to growing WACC value. The growing WACC could have been at least partially offset by increasing share in debt in the capital structure. Average value of WACC for all of the period is $5.7 \%$.

Table 3

WACC of Sectors in Lithuanian Manufacturing Industry, 2001-2016

\begin{tabular}{|c|c|c|c|c|c|}
\hline Code & Name & WACC & Code & Name & WACC \\
\hline $\mathrm{C20}$ & $\begin{array}{l}\text { Chemical } \\
\text { products }\end{array}$ & $8.3 \%$ & C11 & Beverages & $5.3 \%$ \\
\hline $\mathrm{C} 27$ & $\begin{array}{l}\text { Electricity } \\
\text { equipment }\end{array}$ & $7.6 \%$ & C15 & $\begin{array}{c}\text { Leather and } \\
\text { leather } \\
\text { products }\end{array}$ & $5.3 \%$ \\
\hline $\mathrm{C} 26$ & $\begin{array}{l}\text { Computers } \\
\text { and } \\
\text { electronics }\end{array}$ & $7.2 \%$ & $\mathrm{C} 28$ & $\begin{array}{c}\text { Other } \\
\text { machines and } \\
\text { equipment }\end{array}$ & $5.2 \%$ \\
\hline $\mathrm{C29}$ & $\begin{array}{c}\text { Motor } \\
\text { vehicles }\end{array}$ & $6.9 \%$ & C31 & Furniture & $5.2 \%$ \\
\hline $\mathrm{C} 21$ & $\begin{array}{l}\text { Drugs and } \\
\text { medical } \\
\text { products }\end{array}$ & $6.8 \%$ & C32 & $\begin{array}{c}\text { Other } \\
\text { manufacturing } \\
\text { products }\end{array}$ & $5.1 \%$ \\
\hline C13 & Textile & $6.0 \%$ & $\mathrm{C} 22$ & $\begin{array}{c}\text { Rubber and } \\
\text { plastic } \\
\text { products }\end{array}$ & $4.9 \%$ \\
\hline $\mathrm{C} 23$ & $\begin{array}{l}\text { Other non- } \\
\text { metal mineral } \\
\text { products }\end{array}$ & $6.0 \%$ & C18 & $\begin{array}{l}\text { Printing and } \\
\text { reproduction }\end{array}$ & $4.9 \%$ \\
\hline C30 & $\begin{array}{c}\text { Other } \\
\text { transportation } \\
\text { equipment }\end{array}$ & $5.7 \%$ & $\mathrm{C33}$ & $\begin{array}{l}\text { Machinery } \\
\text { repairs and } \\
\text { equipment }\end{array}$ & $4.8 \%$ \\
\hline $\mathrm{C} 17$ & $\begin{array}{l}\text { Paper and } \\
\text { paper } \\
\text { products }\end{array}$ & $5.7 \%$ & C16 & $\begin{array}{l}\text { Timber } \\
\text { products, } \\
\text { excluding } \\
\text { furniture }\end{array}$ & $4.6 \%$ \\
\hline $\mathrm{C} 25$ & $\begin{array}{l}\text { Metal } \\
\text { products, } \\
\text { excluding } \\
\text { machinery }\end{array}$ & $5.6 \%$ & $\mathrm{C10}$ & Food products & $4.5 \%$ \\
\hline C14 & Apparel & $5.5 \%$ & C24 & $\begin{array}{c}\text { Metal } \\
\text { processing }\end{array}$ & $4.3 \%$ \\
\hline
\end{tabular}


Table 3 presents information about average WACC values of different Lithuanian manufacturing sectors, calculated for the period of 2001-2016. Sector with the largest WACC value produces chemical products. Average WACC for chemical producing sector exceeded average value of all manufacturing sectors by 2.6 percentage points. Electricity equipment, computers and electronics, motors vehicles, drugs and medical products, textile, other nonmetal mineral products also contained above average sectoral WACC values. Sector possessing the smallest WACC value during the whole analysed period was metal processing. Average capital cost for the given sector was 1.4 percentage points lower compared to the consolidated sectoral average value. Food products, timber products, machinery repairs and equipment, printing and reproduction, rubber and plastic products, other manufacturing products, furniture, other machines and equipment, leather products, beverages, apparel were able to use cheaper capital, compared to average WACC value of the whole Lithuanian manufacturing sector.

Table 4 presents results of regression equations which analyse effect of different parameters on investment choices in Lithuanian manufacturing sector. First two columns show results of regression equations where all the variables are included with one period time lag compared to investment into tangible and intangible assets variable.

When analysing variables in their regular form, a decrease of WACC by 1 percentage point leads to increase of investments into tangible and intangible assets by 3.61 percentage points. When variables are included into the regression equation in their logarithmic forms, a decline of WACC by 1 percent leads to increase of investments in Lithuanian manufacturing sector by 0.89 percent. Third and fourth columns of table 4 present results where both contemporary and lagged values of independent variables are included into regression equations. With the regular variable forms included into regression WACC decline of 1 percentage point at time period $t$ result in increasing investment of 1.61 percentage points, while decline of WACC by 1 percentage point at time period $t-1$ leads to increase of investment in time period t by 1.73 percentage points. When analysing logarithmic forms of variables, when WACC at time period t declines by 1 percent, it results in increase of investments in Lithuanian manufacturing sector by 0.98 percent. Lagged values of WACC in this situation has no significant effect on investment choices.

It is also worth noting that when EBITDA values are included in regression equation in the logarithmic form, growth in profits of the previous period results in increased investment into tangible and intangible values of Lithuanian manufacturing sector. On the other hand, when profit proxy variable in included in regression equation in its regular form, no significant effect of EBITDA on investment values is witnessed.

\section{Conclusions}

After performed analysis of academic literature, Weighted Average Cost of Capital was chosen as the most widely used method for cost of capital evaluation. Analysis showed that this method has some drawbacks, one of the largest ones being static structure between debt and capital when cost of capital is evaluated in a dynamic manner. In the carried out case study this drawback was overcome, as WACC together with its capital structure for every year was calculated separately. To evaluate cost of equity Capital Asset Pricing Model was chosen. Although opinions between researchers differ concerning the validity of this method, there were no conclusive remarks which strictly denied reliability of CAPM.

Some changes had to be made in order to adopt WACC evaluation methodology for countries where financial markets are still developing, like Lithuania, as rate of market return is not and adequate measure to indicate true market risk. Rate of return for a developing market in the case study was evaluated by adding country's risk premium to base premium of already developed market. Risk premiums of developing markets were evaluated using default spreads of risk-free treasury bonds, estimated from countries credit ratings. Rate of return on debt was calculated by dividing interest payments on residual value of debt.

Tendencies for dynamic change of return on equity and return on debt differ in Lithuanian manufacturing sector.

Table 4

Results of Regression Equations Analysing Effects of Variables on Investment Choices for Consolidated Data of Lithuanian Manufacturing Sector

\begin{tabular}{|c|c|c|c|c|}
\hline & Equation 7, regular & Equation 7, $\log$ & Equation 8, regular & Equation 8, log \\
\hline EBITDA, $t$ & - & - & - & - \\
\hline WACC, $t$ & - & - & $\begin{array}{l}-1.61 \\
(0.03) \\
\end{array}$ & $\begin{array}{l}-0.98 \\
(0.03) \\
\end{array}$ \\
\hline EXP, $t$ & - & - & $\begin{array}{c}0.68 \\
(0.00) \\
\end{array}$ & $\begin{array}{c}4.13 \\
(0.01) \\
\end{array}$ \\
\hline CAP, $t$ & - & - & $\begin{array}{c}-0.09 \\
(0.04)\end{array}$ & $\begin{array}{l}-1.81 \\
(0.00)\end{array}$ \\
\hline EBITDA, t-1 & - & $\begin{array}{c}1.28 \\
(0.00)\end{array}$ & - & $\begin{array}{c}1.35 \\
(0.00)\end{array}$ \\
\hline WACC, t-1 & $\begin{array}{l}-3.61 \\
(0.00)\end{array}$ & $\begin{array}{l}-0.89 \\
(0.02)\end{array}$ & $\begin{array}{l}-1.73 \\
(0.02)\end{array}$ & - \\
\hline EXP, t-1 & $\begin{array}{c}0.55 \\
(0.00)\end{array}$ & $\begin{array}{c}4.12 \\
(0.00)\end{array}$ & - & - \\
\hline CAP, $\mathrm{t}-1$ & - & $\begin{array}{l}-1.43 \\
(0.02)\end{array}$ & - & - \\
\hline $\mathbf{R}^{\wedge} 2$ & 0.68 & 0.72 & 0.72 & 0.64 \\
\hline
\end{tabular}


Comparing results of 2016 to 2009, when global financial and economic crisis hit companies of Lithuanian manufacturing sector the hardest, required return on equity rose by $5 \%$ while required return on debt fell by $55 \%$. Despite the decline in cost of debt, share of debt in total capital fell from $53 \%$ in 2009 down to $43 \%$ in 2016. This structural change was influenced by retained profits, which were not handed out to shareholders as dividends, but invested back into further development of companies performing in Lithuanian manufacturing sector. Cost of capital for these companies could be lowered by distributing part of the profits to the shareholders as dividends and financing further growth by debt capital.

Performed regression analysis suggests that changes in cost of capital of Lithuanian manufacturing sector affect investment decisions. These conclusions persist when the variables are analysed in both their regular and logarithmic forms. This shows that the ability to correctly assess cost of capital value is very important as inappropriate cost of capital estimation can lead to inappropriate investment decisions.

\section{References}

Albanez, T. (2015). Impact of the cost of capital on the financing decisions of Brazilian companies. International Journal of Managerial Finance, 11(3), 285-307. https://doi.org/10.1108/IJMF-02-2014-0026

Arango, H., Bonatto, B. D., Lusvarghi, S. A. S., \& Vasconcelos, G. F. (2013). Methodology for the Regulatory Deflation of the Weighted Average Cost of Capital (WACC) in Electricity Markets. Brazilian Society for Automatics-SBA 2013. https://doi.org/10.1007/s40313-013-0058-6

Aubert, N., Kern, A., \& Hollandts, X. (2017). Employee stock ownership and the cost of capital. Research in International Business and Finance, 41, 67-78. https://doi.org/10.1016/j.ribaf.2017.04.007

Bade, B. (2009). Comment on "The weighted average cost of capital is not quite right". The Quarterly Review of Economics and Finance, 49, 1476-1480. https://doi.org/10.1016/j.qref.2009.05.002

Barth, J. R. (2009). The Rise and Fall of the U.S. Mortgage and Credit Markets. New Jersey: John Wiley \& Sons, Inc, ISBN 978-0-470-47724-3.

Becerra, M. (2009). Theory of the Firm for Strategic Management. Cambridge: Cambridge University Press. ISBN-13 9780-511-50673-4. https://doi.org/10.1017/CBO9780511626524

Belkhir, M., Boubakri, N., \& Grira, J. (2017). Political risk and the cost of capital in the MENA region. Emerging Markets Review, 33, 155-172. https://doi.org/10.1016/j.ememar.2017.08.002

Britzelmaier, B., Kraus, P., Haberle, M., Mayer, B., \& Beck, V. (2013). Cost of capital in SMEs: Theoretical considerations and practical implications of a case study. EuroMed Journal of Business, 8(1), 4-16. https://doi.org/10.1108/EMJB05-2013-0017

Brotherson, W. T., Eades, K. M., Harris, R. S., \& Higgins, R. C. (2013). "Best practices" in estimating the cost of capital: an update. Journal of Applied Finance, 23(1), 15-33.

Cajias, M., Fuerst, F., \& Bienert, S. (2014). Can investing in corporate social responsibility lower a company's cost of capital? Studies in Economics and Finance, 31(2), 202-222. https://doi.org/10.1108/SEF-05-2013-0067

Carluccio J., Mazet-Sonilhac C., \& Mesonnier J. S. (2019). "Investment and the WACC: new micro evidence for France," Working papers 710, Banque de France. https://doi.org/10.2139/ssrn.3347543

Dempsey, M. (1998). The Impact of Personal Taxes on the Firm's Weighted Average Cost of Capital and Investment Behaviour: A Simplified Approach Using the Dempsey Discounted Dividend Model. Journal of Business Finance \& Accounting, 25. (5/6), June/July 1998, 0306-686X. https://doi.org/10.1111/1468-5957.00210

Dutta, S., \& Nezlobin, A. (2017). Information disclosure, firm growth, and the cost of capital. Journal of Financial Economics, 123, 415-431. https://doi.org/10.1016/j.jfineco.2016.04.001

Farber, A. Gillet, R. L., \& Szafarz, A. (2006). A General Formula for the WACC. International Journal of Business, 11(2), 211-218. 
Fatica, S. (2018) Business capital accumulation and the user cost: Is there a heterogeneity bias? Journal of Macroeconomics, 56, 15-34. https://doi.org/10.1016/j.jmacro.2017.12.004

Fernandez, P. (2002). Valuation Methods and Shareholder Value Creation. Academic Press, San Diego, CA. https://doi.org/10.1016/B978-012253841-4.50003-2

Frank, Z. M., \& Shen, T. (2016). Investment and the weighted average cost of capital. Journal of Financial Economics, 119, 300-315. https://doi.org/10.1016/j.jfineco.2015.09.001

Garcia-Sanchez, I. M., \& Noguera-Gamez, L. (2017). Integrated information and the cost of capital. International Business Review, 26, 959-975. https://doi.org/10.1016/j.ibusrev.2017.03.004

Graham, J. R., \& Harvey, C. R. (2001). The theory and practice of corporate finance: Evidence from the field. Journal of Financial Economics, 60, 187-243. https://doi.org/10.1016/S0304-405X(01)00044-7

Grant, J. L. (2003). Foundations of Economic Value Added. Second Edition. New Jersey: John Wiley \& Sons, Inc, ISBN: 0-471-23483-4.

Gupta, K., Krishnamuri, C., \& Tourani-Rad, A. (2018). Financial development, corporate governance and cost of equity capital. Journal of Contemporary Accounting \& Economics, 14, 65-82. https://doi.org/10.1016/j.jcae.2018.02.001

Keef, S. P., Khaled, M. S., \& Roush, M. L. (2012). A note resolving the debate on "The weighted average cost of capital is not quite right". The Quarterly Review of Economics and Finance, 52, 438-442. https://doi.org/10.1016/ j.qref.2012.07.004

Kumar, R. (2016). Valuation Theories and Concepts. San Diego: Academic Press. ISBN 978-0-12-802303-7.

Lim, G. C., \& McNelis, P. D. (2008). Computational Macroeconomics for the Open Economy. Cambridge: The MIT Press. ISBN 978-0-262-12306-8.

Michelfelder, R. A. (2015). Empirical analysis of the generalized consumption asset pricing model: Estimating the cost of capital. Journal of Economics and Business, 80, 37-50. https://doi.org/10.1016/j.jeconbus.2015.04.001

Miles, J. A., \& Ezzell, J. R. (1980). The Weighted Average Cost of Capital, Perfect Capital Markets, and Project Life: A Clarification. Journal of Financial and Quantitative Analysis, 15(3), 719-730. https://doi.org/10.2307/2330405

Miller, R. A. (2009). The weighted average cost of capital is not quite right. The Quarterly Review of Economics and Finance, 49, 128-138. https://doi.org/10.1016/j.qref.2006.11.001

Nahar, S., Azim, M., \& Jubb, C. A. (2016). Risk disclosure, cost of capital and bank performance. International Journal of Accounting \& Information Management, 24(4), 476-494. https://doi.org/10.1108/IJAIM-02-2016-0016

Perez, R. (2011). Finance, governance and management: lessons to be learned from the current crisis. Cambridge: Cambridge University Press. ISBN 978-1-107-00187-9.

Pierru, A. (2009). The weighted average cost of capital is not quite right: A comment. The Quarterly Review of Economics and Finance, 49, 1219-1223. https://doi.org/10.1016/j.qref.2008.08.002

Pratt, S. P., \& Grabowski, R. J. (2010). Cost of Capital. Fourth Edition. New Jersey: John Wiley \& Sons, Inc, ISBN $978-$ 0-470-88656-4.

Rao, R. K. S., \& Stevens, E. C. (2007). A Theory of the Firm's Cost of Capital. Singapore: World Scientific Publishing Co. Pte. Ltd. ISBN-13978-981-256-949-3. https://doi.org/10.1142/6204

Saad, M., \& Samet, A. (2017). Liquidity and the implied cost of equity capital. Journal of International Financial Markets, Institutions \& Money, 51, 15-38. https://doi.org/10.1016/j.intfin.2017.08.007

Schlegel, D. (2015). Cost-of-Capital in Managerial Finance. Switzerland: Springer International Publishing. ISBN 978-3319-15135-9.

Stretcher R., Johnson S. (2011). Capital structure: professional management guidance. Managerial Finance, 37(8), 788804. https://doi.org/10.1108/03074351111146229

Subramanyam, K. R. (2014). Financial Statement Analysis. Eleventh Edition. New York: McGraw-Hill Education. ISBN 978-0-07-811096-2.

Suto, M., \& Takehara, H. (2017). CSR and Cost of Capital: Evidence from Japan. Social Responsibility Journal, 13(4), 798-816. https://doi.org/10.1108/SRJ-10-2016-0170

Wahlen, J. M., Baginski, S. P., \& Bradshaw, M. T. (2010). Financial Reporting, Financial Statement Analysis, and Valuation. 7 Edition. Mason: South-Western Cengage Learning. ISBN-13: 978-0-324-78941-6.

Ward, C. (1999). Estimating the cost of capital. Journal of Corporate Real Estate, 1(3), 287-293. https://doi.org/10. $1108 / 14630019910811088$

The article has been reviewed.

Received in August 2018; accepted in April 2020. 